\title{
Extended Aperture Miniature Antenna Based on CRLH Metamaterials for Wireless Communication Systems Operating Over UHF to C-Band
}

\author{
Mohammad Alibakhshikenari ${ }^{1 *}$, Bal S. Virdee ${ }^{2}$, Abdul Ali ${ }^{1}$, and Ernesto Limiti ${ }^{1}$ \\ ${ }^{1}$ Electronics Engineering Department, University of Rome "Tor Vergata", Via del Politecnico 1, 00133, Rome -
} ITALY

${ }^{2}$ London Metropolitan University, Center for Communications Technology, School of Computing \& Digital Media, London N7 8DB, UK

*alibakhshikenari@ing.uniroma2.it

\begin{abstract}
This paper presents a simple technique to extend the aperture of planar composite right/left-handed (CRLH) metamaterial antennas with minimal impact on the antenna's dimensions. Unlike most CRLH antenna structures the proposed antenna is via-free. The proposed antenna is shown to operate over a wideband from UHF to C-band with good radiation characteristics. The antenna configuration consists of a vertically stacked CRLH unitcells comprising of a patch and meandered lines, where the patch is engraved with an S-shaped slot. The design uses minimal ground plane area. The meander line inductance is grounded using CPW ground which eliminates conventional CRLH TL metallic via into ground plane. The antenna is feed through a coplanar waveguide (CPW) match stub that is electromagnetically coupled to the unit cells. Antenna dimensions are $17.5 \times 32.15 \times 1.6 \mathrm{~mm}^{3}$, which corresponds to $0.204 \lambda_{0} \times 0.375 \lambda_{0} \times 0.018 \lambda_{0}$ where free-space wavelength $\left(\lambda_{0}\right)$ is $3.5 \mathrm{GHz}$. Parametric study enabled the optimization of the antenna performance in terms of impedance bandwidth, radiation gain and radiation efficiency. Measured results confirm the antenna can operate from $850 \mathrm{MHz}$ to $7.90 \mathrm{GHz}$, which is equivalent to a fractional bandwidth of $161.14 \%$. The antenna has a maximum gain and radiation efficiency of $5.12 \mathrm{dBi}$ and $\sim 80 \%$, respectively, at $3.5 \mathrm{GHz}$.
\end{abstract}

Key Terms-Composite right/left-handed metamaterials, planar antenna, slot antenna, wideband, coplanar waveguide, wireless communication systems, portable devices.

\section{INTRODUCTION}

Wireless communication systems are developing at a rapid rate with a requirement to operate seamlessly in various geographical locations. This entails wideband operation to accommodate multiple communications standards. In addition, these devices need to have a compact size and omnidirectional radiation pattern. The size of a conventional antenna however is mainly dictated by its resonance frequency. This limitation has created great interest in the research and development of suitably low profile and high compact antennas [1]. The numerous techniques that have been explored over the recent years to reduce the size of planar antennas are mainly based on the reactive loading of a patch antenna by using high permittivity substrates, shorting pins, or reactive components. More recently composite right/left-handed (CRLH) metamaterials have been widely applied in microwave device and antenna applications due to the unique electromagnetic properties, such as anti-parallel phase, group velocities, and the zero propagation constant [2]. Although CRLH transmission line has been used to design small antennas these antennas typically suffer from narrow bandwidth that restricts their wide applications [3]-[6].

Recently, a number of studies to extend the bandwidth of CRLH antennas have been under investigation [6]-[11]. These antennas implement the CRLH unit cell using inter-digital capacitance and transmission line inductance, which is grounded using a through hole via [6]-[11]. Creating a via-hole adds unnecessary manufacturing complexity to the antenna design which is costly in high volume production, and it can also compromise the characteristics of the antenna due to the parasitic capacitance and inductance. This is a result when the via-hole's characteristic impedance is not properly match with the characteristic impedance of the connecting transmission line. To avoid issues resulting from via-holes and to further extend the impedance bandwidth of planar antennas a novel CRLH antenna design is proposed in this paper. The antenna design is constituted from three CRLH unit cells stacked in a parallel configuration where the radiating patch is embedded with a dielectric slot. The design uses minimal ground plane area and the bandwidth extension using the proposed technique has minimal affect on the antenna's footprint. The highly compact antenna radiates bidirectionally in the E-plane and 
omnidirectionally in the H-plane and operates over a wideband from UHF to C-band. Electrical size of the antenna is measured by its $k a$ value, where $k$ is the wavenumber $(k=2 \pi / \lambda, \lambda=$ wavelength at the operating frequency) and $a$ is the radius of the smallest sphere that circumscribes the antenna. Antennas are considered to be electrically small when $k a \leq 0.5$. The propose antenna satisfies this limit at the low end of the band.

\section{EXTENDED APERTURE ANTENNA DESIGN BASED ON CRLH METAMATERIAL UNIT CELLS}

Aperture of a planar antenna is expanded with minimal impact on its physical footprint using the configuration shown in Fig. 1. This was achieved by implementing a CRLH metamaterial unit cell structure composed of a square patch with two high impedance meander lines. Minimal ground plane area is used by the proposed technique that facilitates a compact design. Unlike in conventional CRLH unit cell the inductive lines are grounded through via-holes. In proposing antenna design instead of via-holes the inductive lines are grounded using an extended strip from the CPW ground plane as shown in Fig. 1. In the structure the meander lines act like shunt left-handed inductance $\left(L_{L}\right)$, and the square patch acts like series left-handed capacitance $\left(C_{L}\right)$. The overall antenna consists of three-unit cells arranged in a parallel configuration and is excited through a balanced coplanar waveguide feed-line that is electromagnetically coupled to the unit cells, as shown in Fig. 1. There is no metallization under the patch and the meander lines. The effective aperture of the antenna was further extended again without increasing the physical dimensions of the antenna by inserting Sshaped slot in the radiating patch. Gap capacitance between the patch is represented by $\left(C_{L}^{\prime}\right)$. The proposed antenna structure henceforth will be referred to as extended composite right/left-handed (E-CRLH) metamaterial (MTM) transmission line antenna.

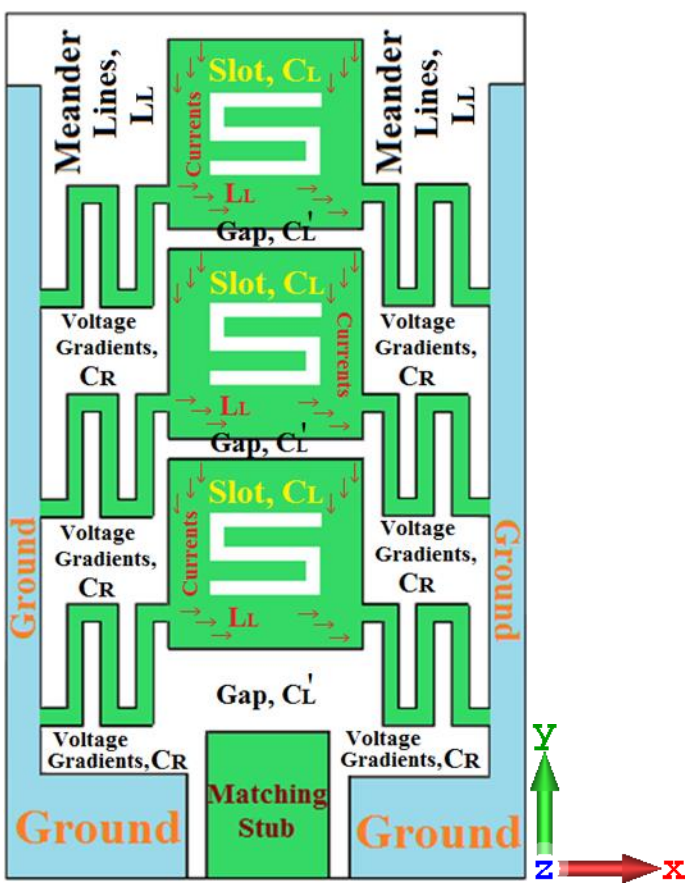

(a)



(b)

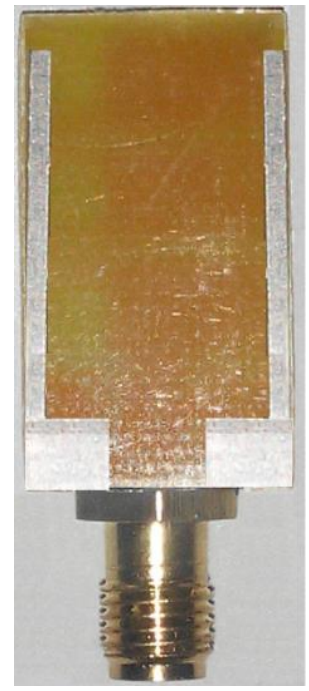

(c)
Fig. 1. Configuration of the extended CRLH metamaterial antenna. a) Layout used in simulation, b) Fabricated prototype, and c) Ground plane (back side). 


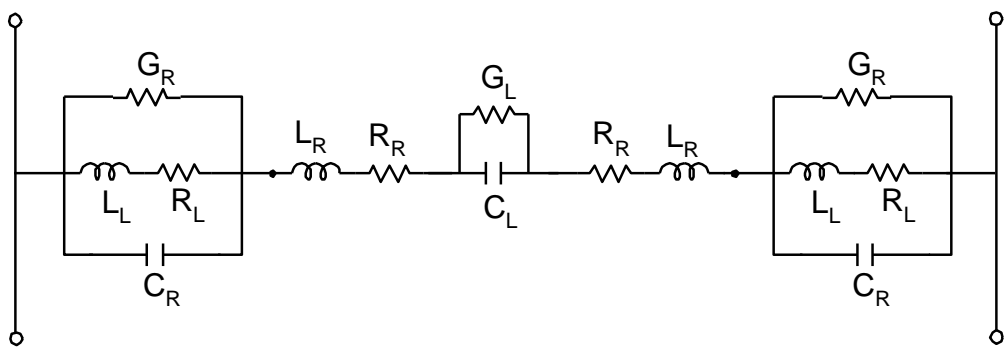

(a)

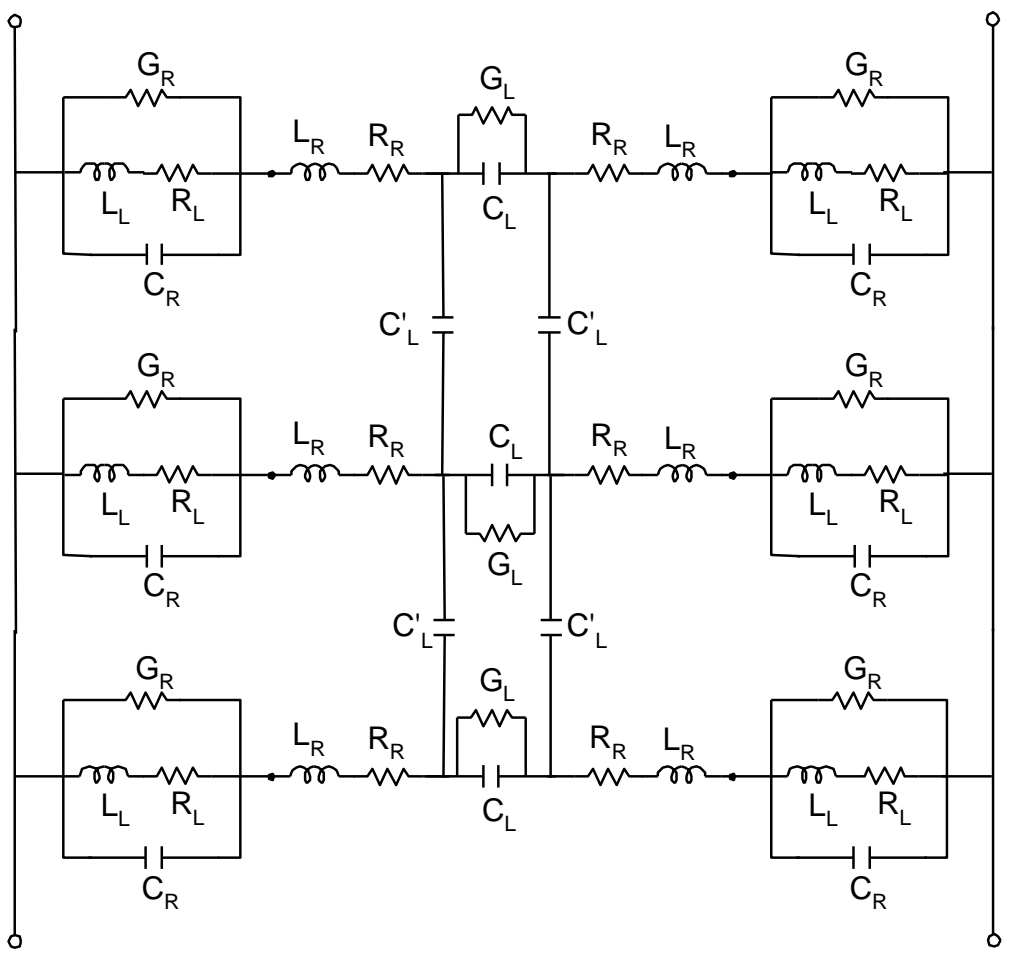

(b)

Fig. 2. Simplified equivalent electrical circuit model of the antenna, a) Unit-cell, and b) Three stack antenna structure.

The equivalent electrical circuit model of the antenna is shown in Fig. 2. Parameters $C_{R}$ and $L_{R}$ are parasitic right-handed (RH) elements that are created by the voltage gradient between the patch and ground plane due to the unwanted currents flowing over the patch. Loss in the circuit is represented by $R_{R}, R_{L}, G_{R}$ and $G_{L}$. Magnitude of these parameters are listed in Table I were determined from full-wave EM simulation using Ansys HFSS ${ }^{\mathrm{TM}}$ by following a well-established procedure and closed form equations in [12]. This information was then used to determine the equivalent electrical circuit model of the antenna, shown in Fig. 2, which was verified using ADS (RF circuit solver).

The antenna was constructed on FR-4 substrate with dielectric constant $\left(\varepsilon_{r}\right)$ of 4.3 , thickness $(h)$ of 1.6 , and loss tangent $(\tan \delta)$ of 0.025 . Antenna's dimensions are $17.5 \times 32.15 \times 1.6 \mathrm{~mm}^{3}$, which is equivalent to $0.204 \lambda_{0} \times 0.375 \lambda_{0} \times 0.018 \lambda_{0}$, respectively, where $\lambda_{0}$ is free-space wavelength at $3.5 \mathrm{GHz}$ at mid-band of frequency where the proposed antenna has resonant.

TABLE I - MAGNITUDES OF RLC COMPONENTS

\begin{tabular}{|c|c|c|c|c|c|c|c|c|}
\hline$R-L-C$ & $C_{L}$ & $L_{L}$ & $C_{R}$ & $L_{R}$ & $R_{R}$ & $R_{L}$ & $G_{R}$ & $G_{L}$ \\
\hline Magnitude & $6.2 \mathrm{pF}$ & $9.5 \mathrm{nH}$ & $2.1 \mathrm{pF}$ & $1.6 \mathrm{nH}$ & $1.8 \Omega$ & $2.0 \Omega$ & $1.5 \mathrm{~S}$ & $1.3 \mathrm{~S}$ \\
\hline
\end{tabular}


As the coaxial feedline is located within the nearfield of the antenna large currents are induced on the sheath of the coaxial feedline that can alter the radiation pattern of the antenna. This was avoided by using ferrite beads as a sheath current choke. Simulated and measured reflection coefficients of the proposed antenna are shown in Fig. 3. Simulations results predict the E-CRLH antenna to operate over a bandwidth defined by $\mathrm{S}_{11}<-10 \mathrm{~dB}$ of $7.23 \mathrm{GHz}$ (from $770 \mathrm{MHz}$ to
$8.00 \mathrm{GHz}$ ), with a fraction bandwidth of $\sim 165 \%$. These results were confirmed with the actual measurements that show the antenna has a bandwidth of $7.05 \mathrm{GHz}$ (from $850 \mathrm{MHz}$ to $7.90 \mathrm{GHz}$ ) with a fractional bandwidth of $160 \%$. The antenna resonates at ten resonance frequencies, which in $\mathrm{GHz}$ are: 1.2, 1.8, 2.4, 3.5, 3.8, 4.2, 5.6, 6.3, 6.9 and 7.5. Over this bandwidth the impedance match is excellent with an optimum of $49 \mathrm{~dB}$ at the fourth resonance frequency of $3.5 \mathrm{GHz}$.

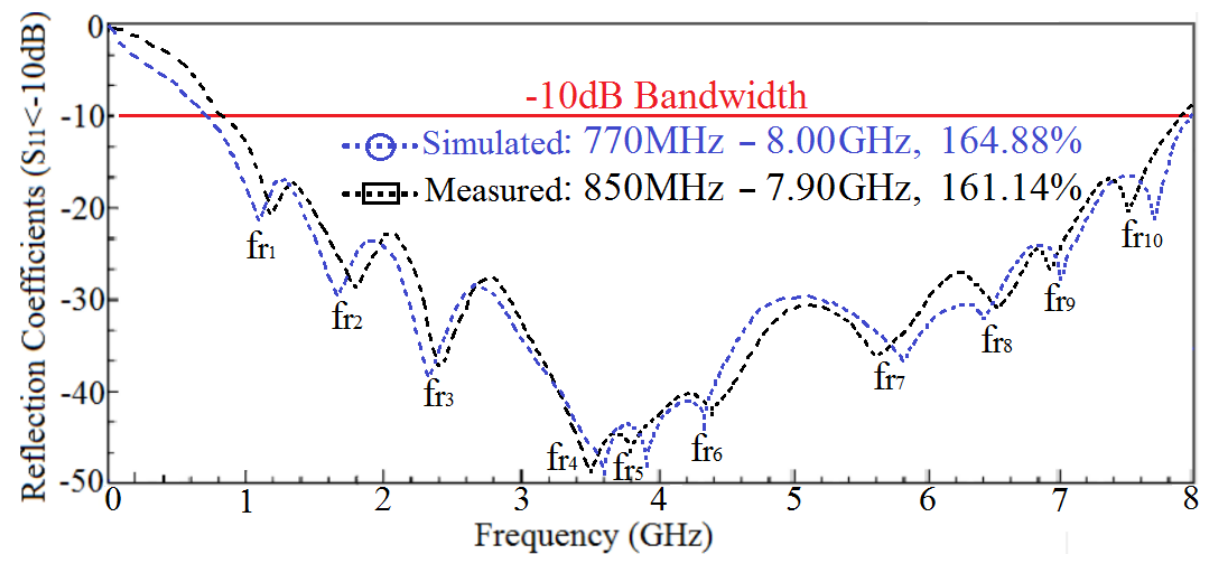

Fig. 3. Simulated and measured reflection coefficients of antenna.

Simulated and measured radiation performance is shown in Fig. 4, and salient features of which are given in Table II. Minimum gain and radiation efficiency are $0.8 \mathrm{dBi}$ and $25.1 \%$, respectively, measured at $850 \mathrm{MHz}$. The measured maximum gain and radiation efficiency are $5.12 \mathrm{dBi}$ and $79.84 \%$, respectively, which were observed at the fourth resonance frequency of $f_{r_{4}}=3.5 \mathrm{GHz}$. There is excellent correlation between the simulated and measured results. The slight difference in between the simulated and measured results is ascribed to the imperfections in the fabrication, i.e. inaccuracy in the etching process and connector soldering.

TABLE II - ANTENNA'S FREQUENCY BANDWIDTH, MATCHING, GAIN AND RADIATION CHARACTERISTICS

Simulated Results

\begin{tabular}{|c|c|c|c|c|c|c|c|c|c|c|c|c|}
\hline Bandwidth (GHz) & \multicolumn{12}{|c|}{7.23} \\
\hline Fractional bandwidth (\%) & \multicolumn{12}{|c|}{164.88} \\
\hline Frequency $(\mathrm{GHz})$ & 0.77 & 1.1 & 1.65 & 2.35 & 3.6 & 3.9 & 4.35 & 5.8 & 6.4 & 7.0 & 7.7 & 8.0 \\
\hline Impedance matching $(\mathrm{dB})$ & -10 & -22 & -30 & -38 & -50 & -48 & -44 & -37 & -33 & -28 & -22 & -10 \\
\hline Gain $(\mathrm{dBi})$ & 0.95 & 1.9 & 3.21 & 4.60 & 5.86 & 5.61 & 4.73 & 4.15 & 3.34 & 2.78 & 1.95 & 1.33 \\
\hline Radiation efficiency (\%) & 28.5 & 55.48 & 64.31 & 70.95 & 83.42 & 80.84 & 75.01 & 64.27 & 57.18 & 52.01 & 44.93 & 38.42 \\
\hline
\end{tabular}

Measured Results

\begin{tabular}{|c|c|c|c|c|c|c|c|c|c|c|c|c|}
\hline Bandwidth (GHz) & \multicolumn{12}{|c|}{7.05} \\
\hline Fractional bandwidth (\%) & \multicolumn{12}{|c|}{161.14} \\
\hline Frequency $(\mathrm{GHz})$ & 0.85 & 1.2 & 1.8 & 2.4 & 3.5 & 3.8 & 4.2 & 5.6 & 6.3 & 6.9 & 7.5 & 7.9 \\
\hline Impedance matching $(\mathrm{dB})$ & -10 & -21 & -28 & -37 & -49 & -46 & -43 & -35 & -31 & -26 & -20 & -10 \\
\hline Gain $(\mathrm{dBi})$ & 0.8 & 1.85 & 3.09 & 4.38 & 5.12 & 5.0 & 4.50 & 3.97 & 3.15 & 2.45 & 1.73 & 1.14 \\
\hline Radiation Efficiency (\%) & 25.1 & 53.15 & 60.72 & 68.60 & 79.84 & 77.10 & 72.15 & 61.88 & 55.32 & 48.67 & 40.30 & 35.84 \\
\hline
\end{tabular}




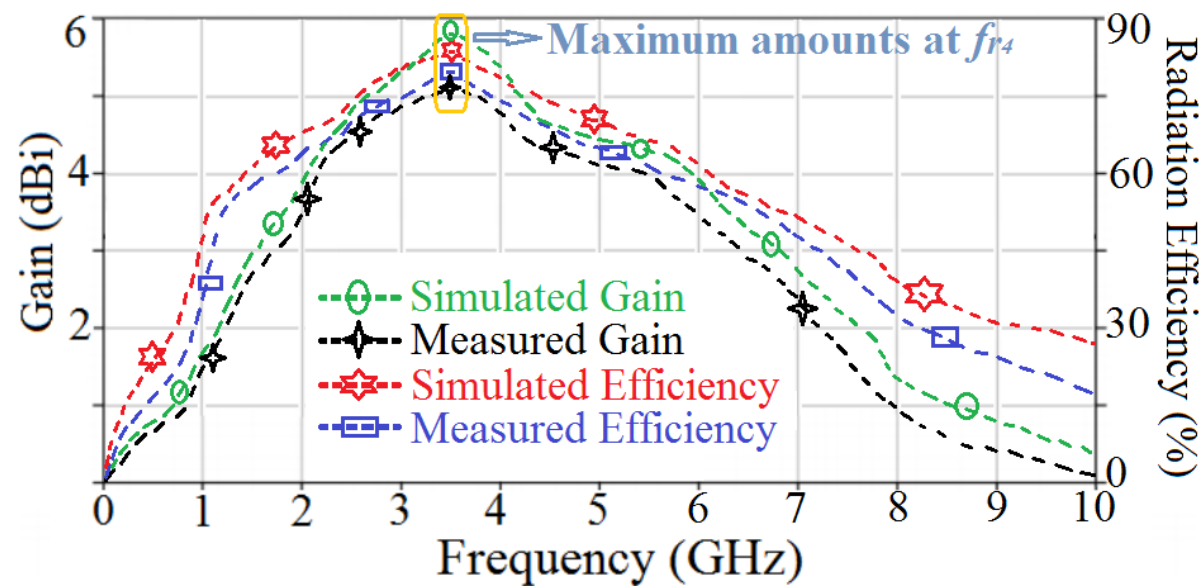

Fig. 4. Simulated and measured radiation gain and efficiency curves versus frequency.

Measured radiation patterns of the proposed antenna in both E- and H-planes for both co- and crosspolarizations are shown in Fig. 5. It is evident from these results the antenna radiates bidirectionally in the E-plane and omnidirectionally in the H-plane. In addition, the antenna's cross-polarization levels at Eplane and $\mathrm{H}$-plane are better than $-5 \mathrm{dBi}$, respectively. Characteristics of the proposed antenna are compared other CRLH antennas in Table III. Compared to the antenna with no via-holes in [13] the meander line inductance connecting the patch to ground-plane is located symmetrically on both sides of the patch, and the structure is excited electromagnetically using a coplanar waveguide feed. In addition, each patch element is embedded with a slot. The results show compared to [13] the proposed design does not compromise the very wide fractional bandwidth but offers a higher gain and radiation efficiency performance. The measured results confirm the proposed E-CRLH antenna works at the following bands: UHF ( $850-1000 \mathrm{MHz}), \mathrm{L}(1-2 \mathrm{GHz}), \mathrm{S}$ (2-4 $\mathrm{GHz})$, and $\mathrm{C}(4-8 \mathrm{GHz})$.
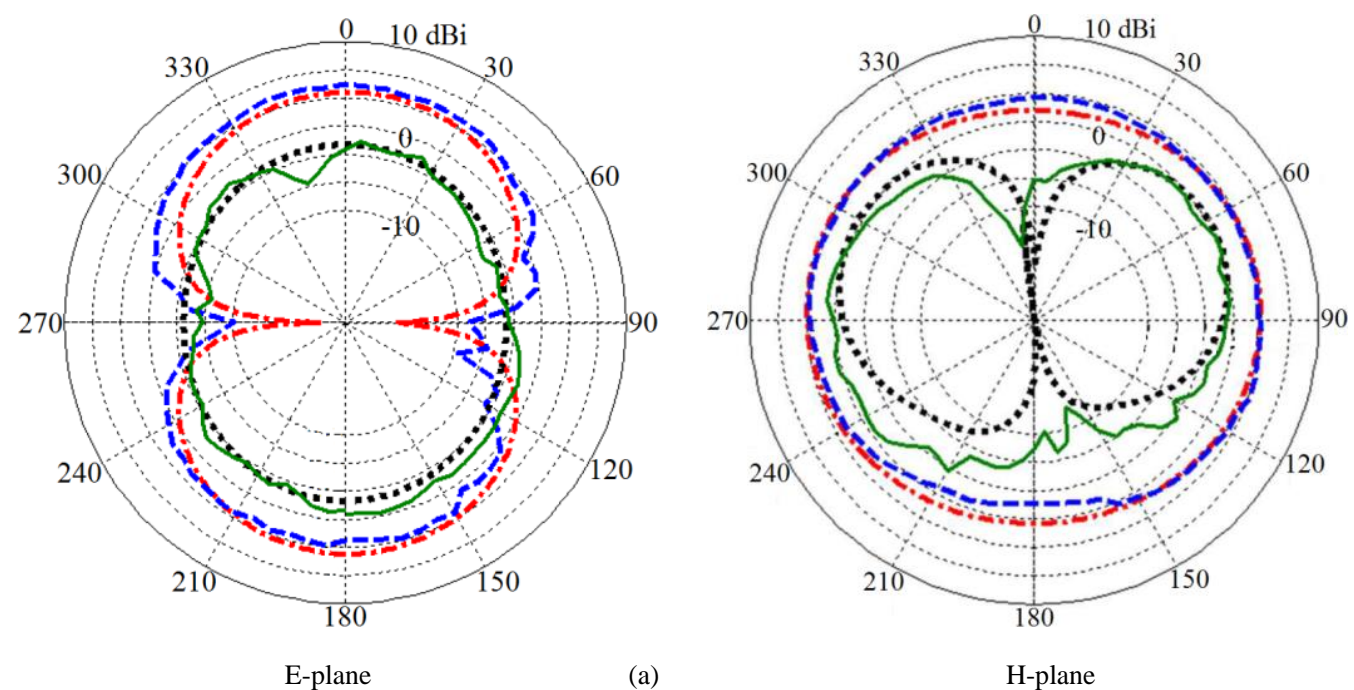

E-plane

(a)

H-plane 

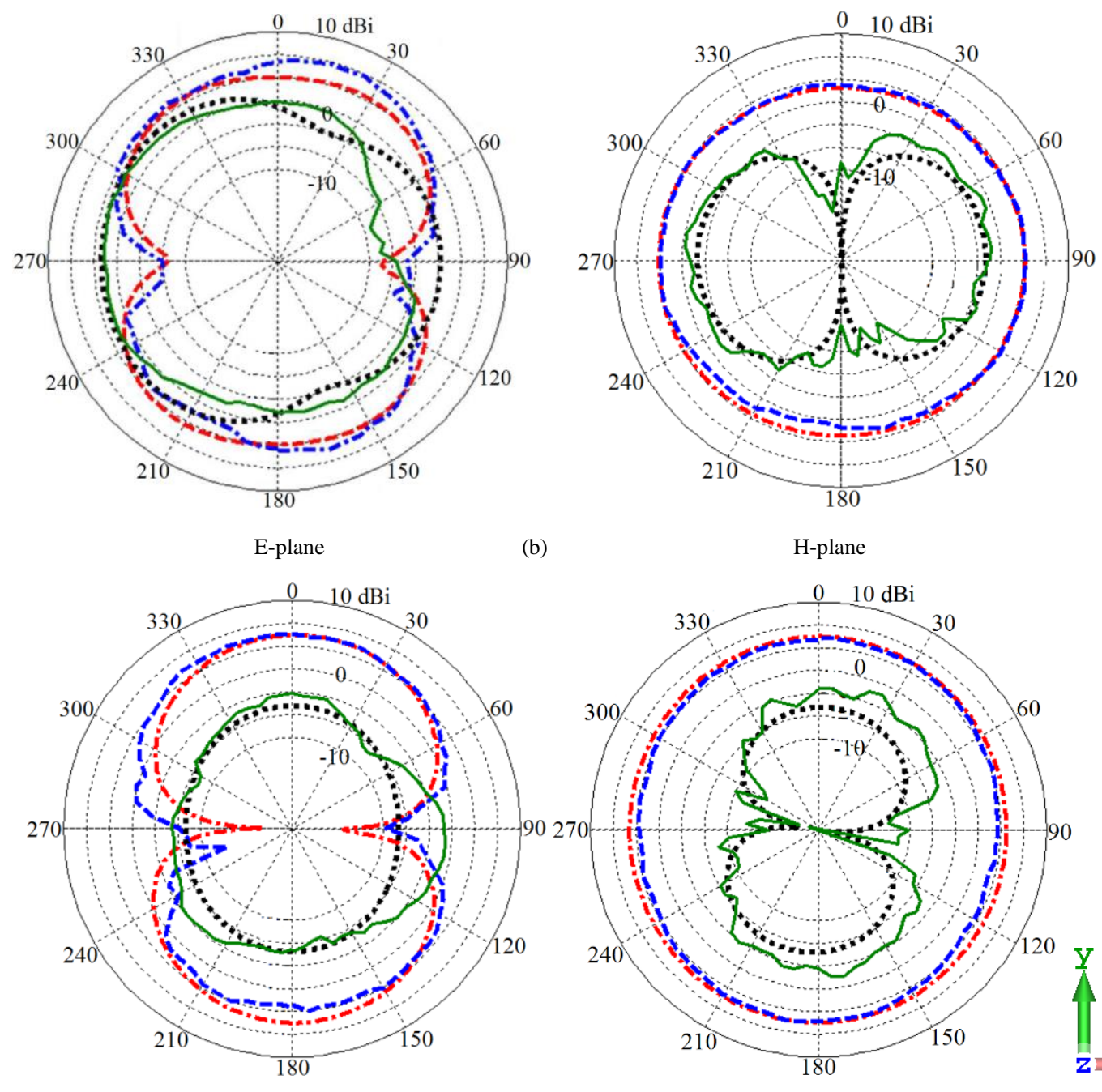

(b)


(c)

H-plane

Fig. 5. Measured co- and cross-polarization radiation patterns for both E- and H-planes at various spot frequencies, a) $f_{r_{1}}=1.2 \mathrm{GHz}$, b) $f_{r_{4}}=3.5$ $\mathrm{GHz}$, c) $f_{r_{10}}=7.5 \mathrm{GHz}$. Red-line is for co-polarization (simulated), blue-line is for co-polarization (measured), black is for cross-polarization (simulated), and green-line is for cross-polarization (measured).

TABLE III - FEATURES OF THE PROPOSED ANTENNA IN COMPARISON WITH RECENTLY REPORTED CRLH ANTENNAS. (NOTE, FB IS FRACTIONAL BANDWIDTH)

\begin{tabular}{|c|c|c|c|c|c|c|c|}
\hline Papers & Dimensions & Bandwidth & $\begin{array}{l}\text { Max. Gain } \\
\quad(\mathrm{dBi})\end{array}$ & $\begin{array}{l}\text { Max. Eff. } \\
(\%)\end{array}$ & Via & $\begin{array}{l}\text { Dielectric } \\
\text { substrate }\end{array}$ & $\begin{array}{c}\text { No. } \\
\text { Resonance } \\
\text { Freq. } \\
\end{array}$ \\
\hline [13] & $\begin{array}{c}25 \times 15 \times 1.6 \mathrm{~mm}^{3} \\
0.12 \lambda_{0} \times 0.07 \lambda_{0} \times 0.008 \lambda_{0} \\
\text { @ } 1.55 \mathrm{GHz}\end{array}$ & $\begin{array}{c}12.7 \mathrm{GHz} \\
(1.55-14.25 \mathrm{GHz}) \\
\mathrm{FB}=160 \%\end{array}$ & 3.5 & - & No & FR-4 & 3 \\
\hline [14] & $\begin{array}{c}50 \times 30 \times 1.6 \mathrm{~mm}^{3} \\
0.20 \lambda_{0} \times 0.12 \lambda_{0} \times 0.006 \lambda_{0} \\
@ 1.2 \mathrm{GHz}\end{array}$ & $\begin{array}{c}\text { (i) } 50 \mathrm{MHz} \\
(1.2-1.25 \mathrm{GHz}) \\
\mathrm{FB}=4.08 \% \\
\text { (ii) } 2.38 \mathrm{GHz} \\
(2.78-5.16 \mathrm{GHz}) \\
\mathrm{FB}=85.13 \% \\
\end{array}$ & $\begin{array}{l}\text { (i) } 1.73 \\
\text { (ii) } 2.26\end{array}$ & $\begin{array}{l}\text { (i) } 73.8 \\
\text { (ii) } 89.4\end{array}$ & No & FR-4 & 3 \\
\hline [15] & $\begin{array}{c}43.8 \times 15 \times 1.57 \mathrm{~mm}^{3} \\
0.49 \lambda_{0} \times 0.17 \lambda_{0} \times 0.017 \lambda_{0} \\
@ 3.38 \mathrm{GHz}\end{array}$ & $\begin{array}{c}- \\
- \\
\mathrm{FB} \\
=\end{array}$ & 5.17 & 91 & Yes & $\begin{array}{c}\text { Rogers } \\
\text { RT/Duroid5880 }\end{array}$ & 1 \\
\hline $\begin{array}{l}{[16]} \\
\text { Sym. }\end{array}$ & $\begin{array}{c}21.4 \times 25.4 \times 1.6 \mathrm{~mm}^{3} \\
0.145 \lambda_{0} \times 0.172 \lambda_{0} \times 0.011 \lambda_{0} \\
@ 2.03 \mathrm{GHz}\end{array}$ & $\begin{array}{c}- \\
- \\
\mathrm{FB}=6.8 \%\end{array}$ & 1.35 & 62 & No & $\begin{array}{c}\text { Rogers } \\
\text { RT/Duroid5880 }\end{array}$ & 1 \\
\hline
\end{tabular}




\begin{tabular}{|c|c|c|c|c|c|c|c|}
\hline $\begin{array}{c}{[16]} \\
\text { Asym. }\end{array}$ & $\begin{array}{c}21.4 \times 25.4 \times 1.6 \mathrm{~mm}^{3} \\
0.107 \lambda_{0} \times 0.127 \lambda_{0} \times 0.008 \lambda_{0} \\
@ 1.5 \mathrm{GHz}\end{array}$ & $\begin{array}{c}- \\
- \\
\mathrm{FB}= \\
=4.8 \%\end{array}$ & -2.15 & 42.5 & No & $\begin{array}{c}\text { Rogers } \\
\text { RT/Duroid5880 }\end{array}$ & 1 \\
\hline [17] & $\begin{array}{c}22.5 \times 13.5 \times 3.175 \mathrm{~mm}^{3} \\
0.247 \lambda_{0} \times 0.148 \lambda_{0} \times 0.034 \lambda_{0} \\
@ 3.3 \mathrm{GHz}\end{array}$ & $\begin{array}{c}100 \mathrm{MHz} \\
(3.23-3.33 \mathrm{GHz}) \\
\mathrm{FB}=3.1 \%\end{array}$ & 0.79 & 65.8 & Yes & $\begin{array}{c}\text { Rogers } \\
\text { RT/Duroid5880 }\end{array}$ & 2 \\
\hline [18] & $\begin{array}{c}12.8 \times 16 \times 1.6 \mathrm{~mm}^{3} \\
0.106 \lambda_{0} \times 0.133 \lambda_{0} \times 0.013 \lambda_{0} \\
@ 2.5 \mathrm{GHz}\end{array}$ & $\begin{array}{c}65 \mathrm{MHz} \\
(2.57-2.635 \mathrm{GHz}) \\
\mathrm{FB}=2.6 \%\end{array}$ & 1.1 & 55 & No & FR-4 & 1 \\
\hline [19] & $\begin{array}{c}32 \times 24 \times 1.59 \mathrm{~mm}^{3} \\
0.261 \lambda_{0} \times 0.196 \lambda_{0} \times 0.0129 \lambda_{0} \\
\text { @ } 2.45 \mathrm{GHz}\end{array}$ & $\begin{array}{c}\text { (i) } 90 \mathrm{MHz} \\
(2.42-2.51 \mathrm{GHz}) \\
\mathrm{FB}=3.65 \% \\
\text { (ii) } 3.2 \mathrm{GHz} \\
(4.52-7.72 \mathrm{GHz}) \\
\text { FB }=52.28 \%\end{array}$ & 1.53 & 89.2 & No & FR-4 & 2 \\
\hline $\begin{array}{l}\text { This } \\
\text { Work }\end{array}$ & $\begin{array}{c}17.5 \times 32.15 \times 1.6 \mathrm{~mm}^{3} \\
0.204 \lambda_{0} \times 0.375 \lambda_{0} \times 0.018 \lambda_{0} \\
\text { @ } 3.5 \mathrm{GHz}\end{array}$ & $\begin{array}{c}7.05 \mathrm{GHz} \\
(0.85-7.9 \mathrm{GHz}) \\
\mathrm{FB}=161.14 \%\end{array}$ & 5.12 & 79.84 & No & FR-4 & 10 \\
\hline
\end{tabular}

\section{PARAMETRIC STUDY}

This section presents a study on the effects of the antenna's performance by its characterizing parameters. Results of this analysis were used to optimize the antenna structure. Since the main aim of the work was to realize a compact antenna design, the effect of unit cells on the antenna reflection coefficient response was necessary. Fig. 6 shows that as the number of unit cells were increased from one to three the bandwidth of the antenna, which is defined for $\mathrm{S}_{11}<-10 \mathrm{~dB}$, correspondingly increased from $3.25 \mathrm{GHz}$ to $7.05 \mathrm{GHz}$. Enhancement in bandwidth observed was $116.9 \%$. The results are summarized in Table IV.

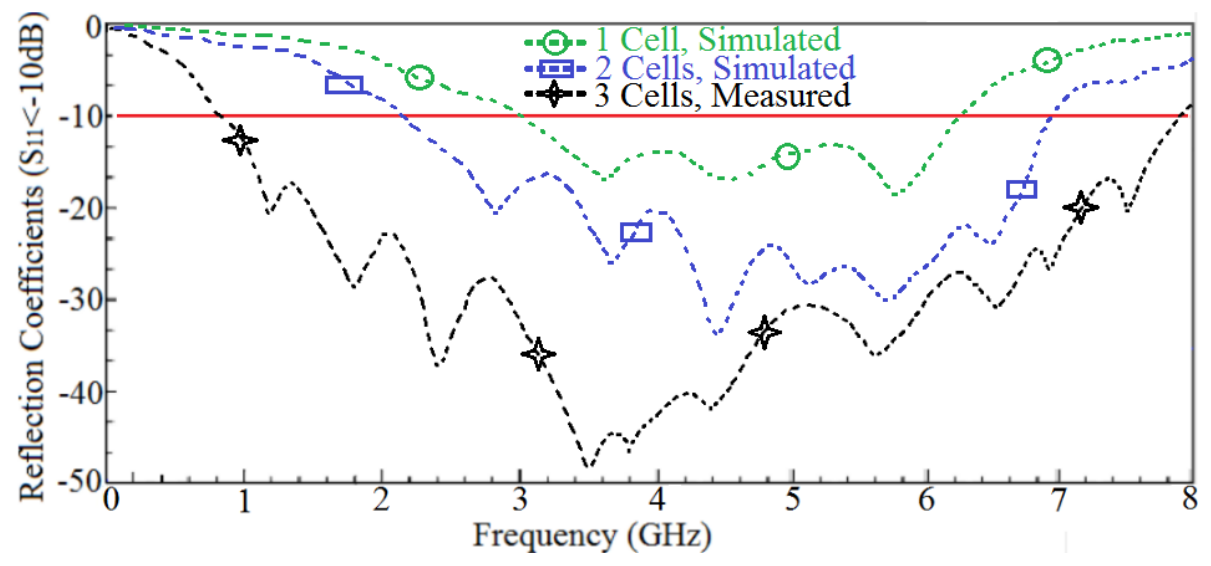

Fig. 6. Parametric study on the reflection coefficient $\left(\mathrm{S}_{11}<-10 \mathrm{~dB}\right)$ by number of unit-cells.

TABLE IV - BANDWIDTH AND FRACTIONAL BANDWIDTH OBTAINED FROM THE PARAMETRIC STUDY

\begin{tabular}{|c|c|c|c|}
\hline No. of unit cells & Impedance bandwidth & Frequency range & Fractional Bandwidth \\
\hline 1 & $3.25 \mathrm{GHz}$ (Sim.) & $3.0 \mathrm{GHz}$ to $6.25 \mathrm{GHz}$ & $70.27 \%$ \\
\hline 2 & $4.75 \mathrm{GHz}$ (Sim.) & $2.18 \mathrm{GHz}$ to $6.93 \mathrm{GHz}$ & $104.28 \%$ \\
\hline 3 & $7.05 \mathrm{GHz}$ (Meas.) & $0.85 \mathrm{GHz}$ to $7.90 \mathrm{GHz}$ & $161.14 \%$ \\
\hline
\end{tabular}

Effect of number of the unit cells on the radiation gain presented in Fig. 7 shows that by increasing the number of unit cells from one to three, the maximum radiation gain correspondingly increased from $1.3 \mathrm{dBi}$ at $5 \mathrm{GHz}$ to $5.12 \mathrm{dBi}$ at $3.5 \mathrm{GHz}$. This change constitutes a significant improvement by
293.8\%. Fig. 8 shows how the radiation efficiency is affected by increasing the number of unit cells from 1 cell to 3 cells. The maximum radiation efficiency is $20 \%$ at $5 \mathrm{GHz}$ (for one cell) which increases to $\sim 80 \%$ at $3.5 \mathrm{GHz}$ (for three cells). Substantial improvement of $300 \%$ is achieved in radiation efficiency. 


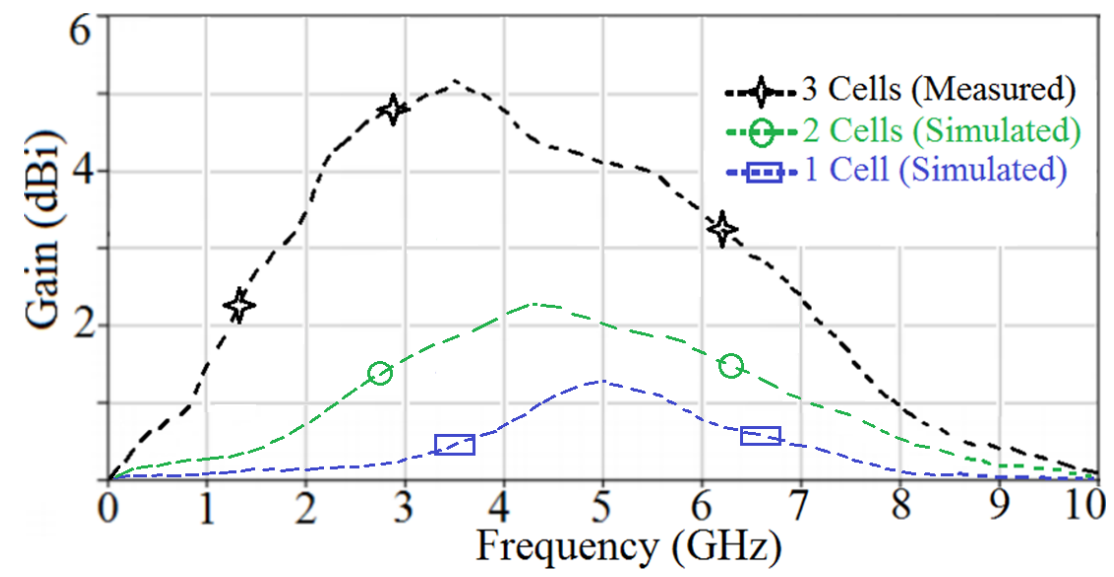

Fig. 7. Effect of number of unit-cells on the antenna's radiation gain.

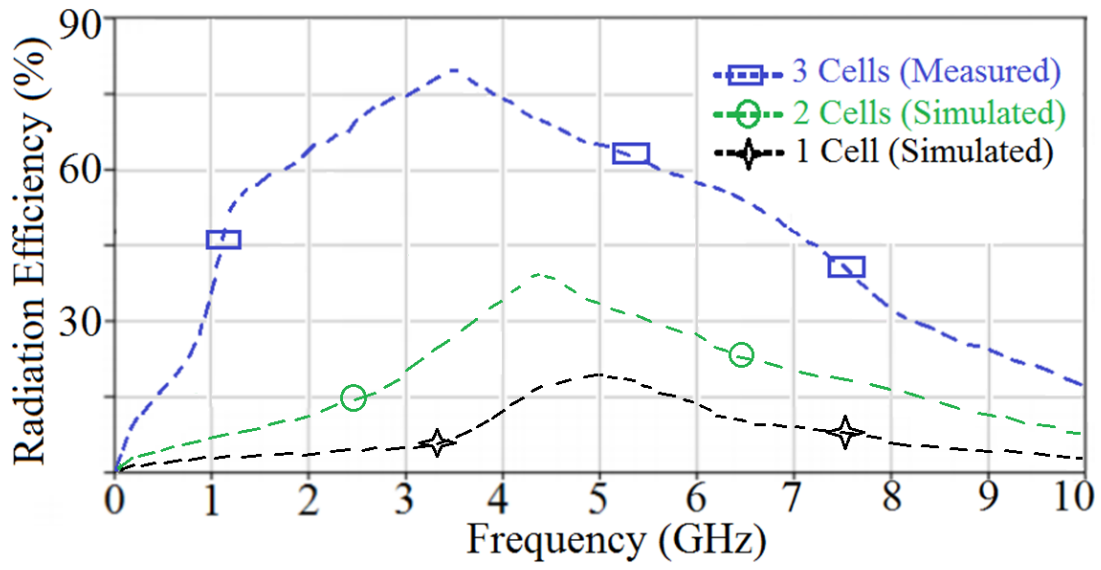

Fig. 8. Parametric study on the radiation efficiency by number of unit-cells.

The effect on the antenna's performance by the various elements, i.e. patch, S-shaped slot, and the two meander lines (ML), that constitute the E-CRLH unit cell was also investigated. Several antennas were constructed which were constituted from (i) just the patch, (ii) patch and the left meander line, (iii) patch with S-shaped slot and left-hand meander line, and (iv) patch with S-shaped slot and the two meander lines. Fig. 9 shows how the gain and radiation efficiency of the antenna alter as various elements are added to realize the finalized antenna. The results show that as the various elements are added the gain and radiation efficiency of the unit cell improve correspondingly. The optimum gain and radiation efficiency are observed at around $5 \mathrm{GHz}$. The gain increases from $-0.05 \mathrm{dBi}$ at $4.75 \mathrm{GHz}$ (patch only) to $1.3 \mathrm{dBi}$ at $5 \mathrm{GHz}$ (patch+ML+ slot+ML), which is an improvement of $1.35 \mathrm{dBi}$. The maximum radiation efficiency increases from $6.7 \%$ at $4.8 \mathrm{GHz}$ (patch only) to $20 \%$ at $5 \mathrm{GHz}$ (patch+ML+slot+ML), which is an improvement of 13.3\%. Salient features are given in Tables V and VI. 


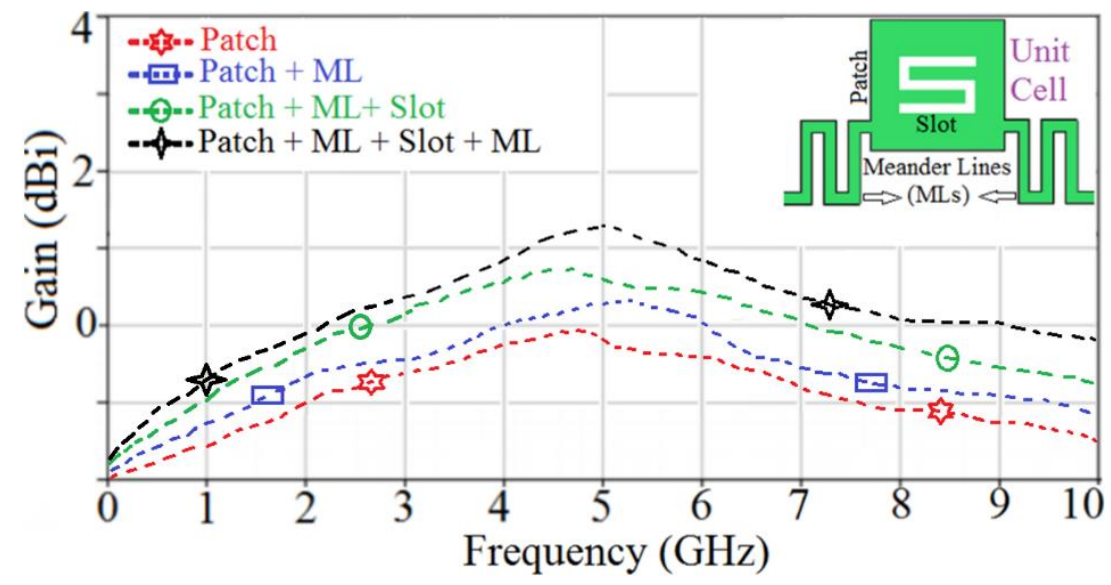

(a)



(b)

Fig. 9. Effect of the various elements constituting the E-CRLH unit cell on the antenna's (a) Effect of antenna's gain performance, and (b) Effect on the antenna's radiation efficiency performance.

TABLE V - RADIATION GAIN OBTAINED FROM THE PARAMETRIC STUDY

\begin{tabular}{|c|c|c|c|c|}
\cline { 2 - 5 } \multicolumn{1}{c|}{} & Patch & Patch + ML & Patch + ML + Slot & Patch + ML + Slot + ML \\
\hline Frequency $(\mathrm{GHz})$ & 4.75 & 5.3 & 4.6 & 5.0 \\
\hline Max. Gain $(\mathrm{dBi})$ & -0.05 & 0.35 & 0.8 & 1.3 \\
\hline
\end{tabular}

TABLE VI - RADIATION EFFICIENCY OBTAINED FROM THE PARAMETRIC STUDY

\begin{tabular}{|c|c|c|c|c|}
\cline { 2 - 5 } \multicolumn{1}{c|}{} & Patch & Patch + ML & Patch + ML + Slot & Patch + ML + Slot + ML \\
\hline Frequency $(\mathrm{GHz})$ & 4.8 & 5.45 & 4.85 & 5.0 \\
\hline Max. efficiency $(\%)$ & 6.7 & 11.5 & 18 & 20 \\
\hline
\end{tabular}

The effect on the antenna's performance by the dimensions of S-shaped slot, meander line, and matching stub were also investigated. Optimized dimensions of the finalized E-CRLH antenna are given in Table VII, which correspond to the annotated numeral label on the antenna structure shown in Fig. 10. 


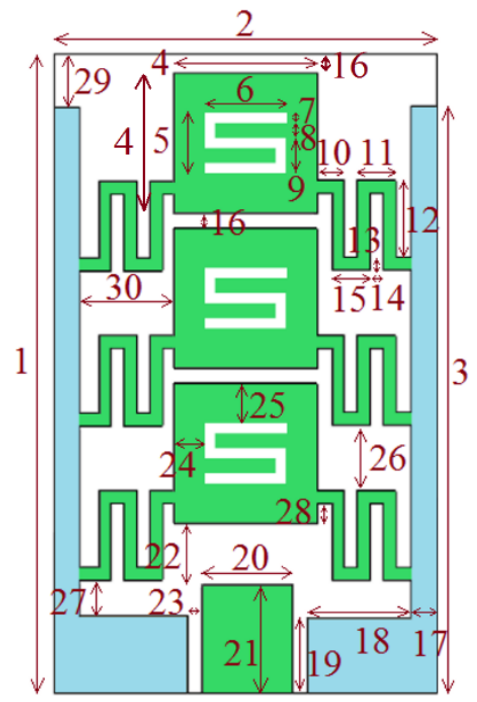

Fig. 10. Proposed antenna with numerical labels. The patches are square of side \#4.

TABLE VII - ANTENNA DIMENSIONS

Antenna dimensions corresponding to the numerical labels in the Fig.10.

\begin{tabular}{|c|c|c|c|c|c|c|c|c|c|c|}
\hline Label No. & 1 & 2 & 3 & 4 & 5 & 6 & 7 & 8 & 9 & 10 \\
\hline Dimensions (mm) & 32.15 & 17.5 & 29.15 & 7 & 3 & 4 & 0.5 & 0.7 & 1.8 & 1.1 \\
\hline
\end{tabular}

\begin{tabular}{|c|c|c|c|c|c|c|c|c|c|c|}
\hline Label No. & 11 & 12 & 13 & 14 & 15 & 16 & 17 & 18 & 19 & 20 \\
\hline Dimensions (mm) & 2.1 & 4 & 0.5 & 0.5 & 2 & 0.65 & 1.05 & 5 & 3 & 3.5 \\
\hline
\end{tabular}

\begin{tabular}{|c|c|c|c|c|c|c|c|c|c|c|}
\hline Label No. & 21 & 22 & 23 & 24 & 25 & 26 & 27 & 28 & 29 & 30 \\
\hline Dimensions (mm) & 6 & 3.2 & 0.5 & 1.7 & 2 & 2.2 & 1.8 & 0.8 & 3 & 4.2 \\
\hline
\end{tabular}

The influence of the slot's length and width on antenna's reflection coefficients, number of resonance frequencies and impedance matching was studied too. The effect by these parameters on the antenna's reflection coefficient is shown in Fig.11. Clearly, by increasing the length of the $\mathrm{S}$-shaped slit from $1 \mathrm{~mm}$ to $3 \mathrm{~mm}$, and its width from $2 \mathrm{~mm}$ to $4 \mathrm{~mm}$, increases the antenna's bandwidth from $5.1 \mathrm{GHz}$ to $7.05 \mathrm{GHz}$, which is equivalent to $38 \%$ enhancement in the frequency bandwidth. In this study, all other structural dimensions were unchanged. In addition, the impedance matching of the antenna improved from $-35 \mathrm{~dB}$ at $5.4 \mathrm{GHz}$ to -49 $\mathrm{dB}$ at $3.5 \mathrm{GHz}$. Salient features of this study are given in Table VIII.

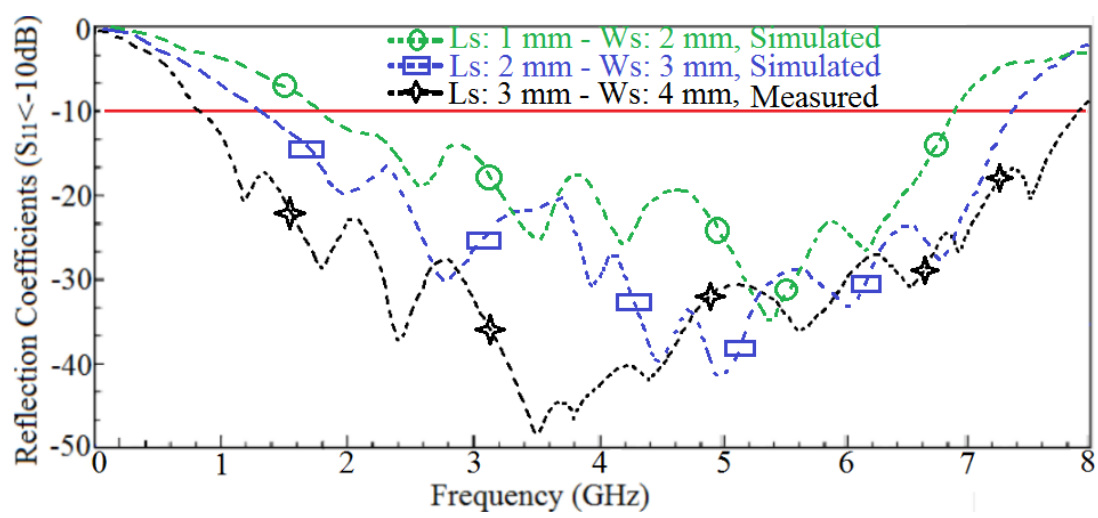

Fig. 11. Effect of slots dimensions on the antenna's reflection coefficient $\left(\mathrm{S}_{11}<-10 \mathrm{~dB}\right)$. 
TABLE VIII - EFFECT OF S-SHAPED SLIT ON THE ANTENNA’s REFLECTION COEFFICIENT, RESONANCE FREQUENCIES, AND IMPEDANCE MATCHING

\begin{tabular}{|c|c|c|c|c|c|c|c|c|}
\hline $\begin{array}{c}\mathrm{L}_{\mathrm{S}} / \mathrm{W}_{\mathrm{S}} \\
(\mathrm{mm})\end{array}$ & \multicolumn{9}{|c|}{ S-shaped slot } \\
\hline \multirow{2}{*}{$1 / 2$} & Bandwidth / FB & \multicolumn{7}{|c|}{$5.1 \mathrm{GHz}(1.8 \mathrm{GHz}$ to $6.9 \mathrm{GHz}) / 117.24 \%$} \\
\cline { 2 - 8 }$(\mathrm{Sim})$. & Frequency $(\mathrm{GHz})$ & 1.8 & 2.6 & 3.55 & 4.2 & 5.2 & 6.18 & 6.9 \\
\cline { 2 - 9 } & Match (dB) & -10 & -19 & -25 & -27 & -35 & -26 & -10 \\
\hline
\end{tabular}

\begin{tabular}{|c|c|c|c|c|c|c|c|c|c|c|}
\hline $\mathrm{L}_{\mathrm{S}} / \mathrm{W}_{\mathrm{S}}$ & \multicolumn{10}{|c|}{ S-shaped slot } \\
\hline \multirow{3}{*}{$\begin{array}{c}2 / 3 \\
\text { (Sim.) }\end{array}$} & Bandwidth / FB & \multicolumn{9}{|c|}{$6.1 \mathrm{GHz}(1.3 \mathrm{GHz}$ to $7.4 \mathrm{GHz}) / 140.22 \%$} \\
\hline & Frequency $(\mathrm{GHz})$ & 1.3 & 2.0 & 2.8 & 4.95 & 4.45 & 5.0 & 6.0 & 6.7 & 7.4 \\
\hline & Match $(\mathrm{dB})$ & -10 & -20 & -30 & -31 & -40 & -42 & -33 & -27 & -10 \\
\hline
\end{tabular}

\begin{tabular}{|c|c|c|c|c|c|c|c|c|c|c|c|c|c|}
\hline $\mathrm{L}_{\mathrm{S}} / \mathrm{W}_{\mathrm{S}}$ & \multicolumn{13}{|c|}{ S-shaped slot } \\
\hline \multirow{3}{*}{$\begin{array}{c}3 / 4 \\
\text { (Meas.) }\end{array}$} & Bandwidth / FB & \multicolumn{12}{|c|}{$7.05 \mathrm{GHz}(0.85 \mathrm{GHz}$ to $7.9 \mathrm{GHz}) / 161.14 \%$} \\
\hline & Frequency $(\mathrm{GHz})$ & 0.85 & 1.2 & 1.8 & 2.4 & 3.5 & 3.8 & 4.2 & 5.6 & 6.3 & 6.9 & 7.5 & 7.9 \\
\hline & Match $(\mathrm{dB})$ & -10 & -21 & -28 & -37 & -49 & -46 & -43 & -35 & -31 & -26 & -20 & -10 \\
\hline
\end{tabular}

The effect of length and width of the meander lines (MLs) on antenna properties were carefully evaluated. The results are presented in Fig.12, and in Table IX. It is evident that when the length and width of MLs are increased the impedance bandwidth and number of resonance frequencies also increase. The length of the meander lines was extended from $2.5 \mathrm{~mm}$ to $4.5 \mathrm{~mm}$ and their width from $2.2 \mathrm{~mm}$ to $4.2 \mathrm{~mm}$. All other parameters in this study were unchanged. Optimum dimensions of the meander line length and width of $4.5 \mathrm{~mm}$ and $4.2 \mathrm{~mm}$, respectively, provided an impedance bandwidth improvement of $15 \%$.



Fig. 12. Parametric study on reflection coefficient $\left(\mathrm{S}_{11}<-10 \mathrm{~dB}\right)$ by meander Line's dimensions (Length and width of ML).

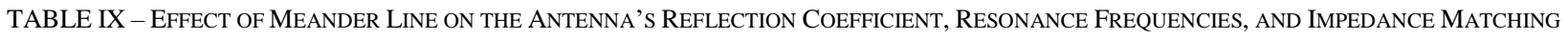

\begin{tabular}{|c|c|c|c|c|c|c|c|c|c|c|}
\hline $\mathrm{L}_{\mathrm{ML}} / \mathrm{W}_{\mathrm{ML}}$ & \multicolumn{10}{|c|}{ Meander Line (ML) } \\
\hline \multirow{3}{*}{$\begin{array}{c}2.5 / 2.2 \\
(\mathrm{~mm}) \\
\text { (Simulated) }\end{array}$} & $\mathrm{BW}$ & \multicolumn{9}{|c|}{$\begin{array}{l}6.15 \mathrm{GHz} \text { (from } 1.4 \text { to } 7.55 \mathrm{GHz} \text { ) } \\
\text { Corresponds to a fractional bandwidth of } 137.43 \%\end{array}$} \\
\hline & Frequency (GHz) & 1.4 & 2.2 & 3.05 & 4.25 & 4.9 & 6.2 & 6.8 & 7.55 & - \\
\hline & Imp. Mat. (dB) & -10 & -17 & -21 & -30 & -32 & -36 & -32 & -10 & - \\
\hline $\mathrm{L}_{\mathrm{ML}} / \mathrm{W}_{\mathrm{ML}}$ & \multicolumn{10}{|c|}{ Meander Line (ML) } \\
\hline \multirow{3}{*}{$\begin{array}{c}3.5 / 3.2 \\
(\mathrm{~mm}) \\
\text { (Simulated) }\end{array}$} & BW & \multicolumn{9}{|c|}{$\begin{array}{l}6.62 \mathrm{GHz} \text { (from } 1.08 \mathrm{GHz} \text { to } 7.7 \mathrm{GHz} \text { ) } \\
\text { Corresponds to a fractional bandwidth of } 150.79 \%\end{array}$} \\
\hline & Frequency $(\mathrm{GHz})$ & 1.08 & 1.6 & 2.3 & 3.7 & 4.15 & 5.15 & 5.8 & 6.5 & 7.15 \\
\hline & Imp. Mat. (dB) & -10 & -20 & -25 & -38 & -38 & -34 & -32 & -32 & -26 \\
\hline
\end{tabular}




\begin{tabular}{|c|c|c|c|c|c|c|c|c|c|c|}
\hline $\mathrm{L}_{\mathrm{ML}} / \mathrm{W}_{\mathrm{ML}}$ & \multicolumn{10}{|c|}{ Meander Line (ML) } \\
\hline \multirow{3}{*}{$\begin{array}{c}4.5 / 4.2 \\
(\mathrm{~mm}) \\
\text { (Measured) }\end{array}$} & BW & \multicolumn{9}{|c|}{$\begin{array}{l}7.05 \mathrm{GHz} \text { (from } 0.85 \mathrm{GHz} \text { to } 7.9 \mathrm{GHz} \text { ) } \\
\text { Corresponds to a fractional bandwidth of } 161.14 \%\end{array}$} \\
\hline & Frequency $(\mathrm{GHz})$ & 0.85 & 1.2 & 1.8 & 2.4 & 3.5 & 3.8 & 4.2 & 5.6 & 6.3 \\
\hline & Imp. Mat. (dB) & -10 & -21 & -28 & -37 & -49 & -46 & -43 & -35 & -31 \\
\hline
\end{tabular}

Finally, the influence of the matching stub's dimensions on the antenna's performance was evaluated too. The results are presented in Fig.13 and salient features are given in Table $\mathrm{X}$. Results show that by increasing the length and width of the matching stub can also enhance the antenna's impedance matching property. When the length and width of matching stub were increased from $2.3 \mathrm{~mm}$ to $4.3 \mathrm{~mm}$ and $1 \mathrm{~mm}$ to 3 $\mathrm{mm}$, respectively, the impedance bandwidth improved by $13.2 \%$. All other parameters were unchanged.

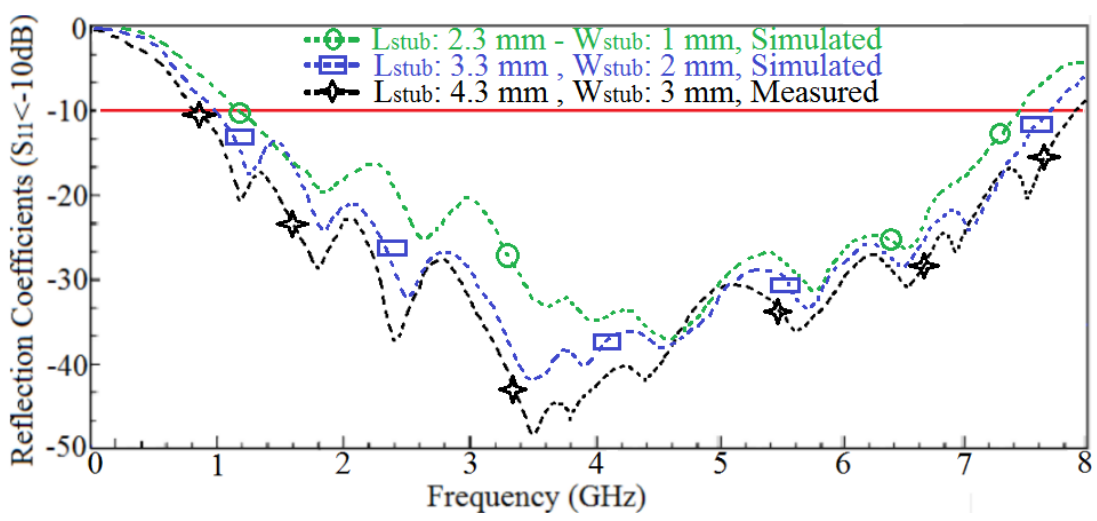

Fig. 13. Parametric study on reflection coefficient $\left(\mathrm{S}_{11}<-10 \mathrm{~dB}\right)$ by matching stub's dimensions (Length and width of stub).

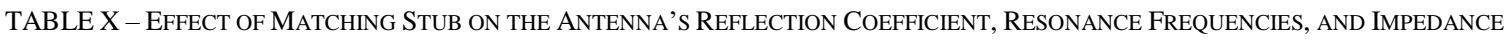
MATCHING

\begin{tabular}{|c|c|c|c|c|c|c|c|c|c|c|}
\hline $\mathrm{L}_{\text {stub }} / \mathrm{W}_{\text {stub }}$ & \multicolumn{10}{|c|}{ Matching Stub } \\
\hline \multirow[t]{3}{*}{$\begin{array}{l}2.3 / 1(\mathrm{~mm}) \\
\text { (Simulated) }\end{array}$} & BW & \multicolumn{9}{|c|}{$\begin{array}{l}6.27 \mathrm{GHz} \text { (from } 1.15 \mathrm{GHz} \text { to } 7.42 \mathrm{GHz} \text { ) } \\
\text { Corresponds to a fractional bandwidth of } 146.32 \%\end{array}$} \\
\hline & Frequency $(\mathrm{GHz})$ & 1.15 & 1.8 & 2.6 & 3.6 & 4.0 & 4.6 & 5.8 & 6.5 & -7.42 \\
\hline & Imp. Mat. (dB) & -10 & -20 & -25 & -33 & -35 & -37 & -31 & -2.6 & -10 \\
\hline
\end{tabular}

\begin{tabular}{|c|c|c|c|c|c|c|c|c|c|c|}
\hline \multirow{2}{*}{$\mathrm{L}_{\text {stub }} / \mathrm{W}_{\text {stub }}$} & \multicolumn{10}{|c|}{ Matching Stub } \\
\hline $\begin{array}{c}3.3 / 2(\mathrm{~mm}) \\
\text { (Simulated) }\end{array}$ & $\mathrm{BW}$ & \multicolumn{8}{|c|}{$6.7 \mathrm{GHz}$ (from $1.0 \mathrm{GHz}$ to $7.7 \mathrm{GHz})$} \\
& & \multicolumn{8}{|c|}{ Corresponds to a fractional bandwidth of $154.02 \%$} \\
\cline { 2 - 11 } & Frequency $(\mathrm{GHz})$ & 1.0 & 1.25 & 1.8 & 2.5 & 3.5 & 3.9 & 4.5 & 5.7 & 6.5 \\
\cline { 2 - 11 } & Imp. Mat. (dB) & -10 & -17 & -24 & -32 & -42 & -40 & -38 & -33 & -28 \\
\hline
\end{tabular}

\begin{tabular}{|c|c|c|c|c|c|c|c|c|c|c|}
\hline $\mathrm{L}_{\text {stub }} / \mathrm{W}_{\text {stub }}$ & \multicolumn{10}{|c|}{ Matching Stub } \\
\hline \multirow{3}{*}{$\begin{array}{c}4.3 / 3(\mathrm{~mm}) \\
\text { (Measured) }\end{array}$} & BW & \multicolumn{9}{|c|}{$\begin{array}{c}7.05 \mathrm{GHz}(0.85 \mathrm{GHz} \text { to } 7.9 \mathrm{GHz}) \\
\text { Corresponds to a fractional bandwidth of } 161.14 \%\end{array}$} \\
\hline & Frequency $(\mathrm{GHz})$ & 0.85 & 1.2 & 1.8 & 2.4 & 3.5 & 3.8 & 4.2 & 5.6 & 6.3 \\
\hline & Imp. Mat. (dB) & -10 & -21 & -28 & -37 & -49 & -46 & -43 & -35 & -31 \\
\hline
\end{tabular}

\section{CONCLUSION}

A novel technique was presented to enhance the impedance bandwidth of planar antennas implemented using CRLH metamaterial unit cells with minimal ground plane and marginal effect on the antenna size. This was achieved by vertically stacking three CRLH unit cells, which had an S-shaped slot engraved on the radiating patch, and where the structure was excited electromagnetically using a coplanar waveguide feed. Unlike conventional CRLH antennas the proposed design is via-free and implemented using distributed transmission lines. The influence of the geometrical parameters of the antenna on its performance has been investigated to determine the optimal design. The performance of the antenna design was verified 
experimentally. The antenna exhibited an impedance bandwidth from $850 \mathrm{MHz}$ to $7.90 \mathrm{GHz}$ for $\mathrm{S}_{11}<-10 \mathrm{~dB}$, which is equivalent to a fractional bandwidth of $161.14 \%$. It gain varied from a minimum of $0.8 \mathrm{dBi}$ at $850 \mathrm{MHz}$ to a maximum of $5.12 \mathrm{dBi}$ at $3.5 \mathrm{GHz}$. Its radiation efficiency varied from $25.1 \%$ at $850 \mathrm{MHz}$ to a maximum of $\sim 80 \%$ at $3.5 \mathrm{GHz}$. The proposed antenna radiates bidirectionally in the E-plane and omnidirectionally in the H-plane. The antenna is highly compact with dimensions of $17.5 \times 32.15 \times 1.6 \mathrm{~mm}^{3}$. As a result, these features enable the proposed antenna for use in the wireless communication systems and portable devices.

\section{ACKNOWLEDGMENT}

The data used are listed in the references, tables and figures. The readers can contact with Mr. Mohammad Alibakhshikenari by sending email to alibakhshikenari@ing.uniroma2.it.

\section{REFERENCES}

[1] M. Alibakhshi-Kenari, M. Naser-Moghadasi, R. A. Sadeghzadeh, B. S. Virdee and E. Limiti, "Bandwidth extension of planar antennas using embedded slits for reliable multiband RF communications," AEUE Elsevier Int. J. of Electronics and Communications, Vol. 70, Issue 7, July 2016, pp. 910-919.

[2] C. Caloz, T. Itoh, Electromagnetic Metamaterials: Transmission Line Theory and Microwave Applications, Dec. 2005, WileyIEEE Press.

[3] M. A. Abdalla, M. I. Abdelnaser, "A compact dual band DCRLH antenna with radiation pattern directional characteristics," IEEE International Symposium on Antennas and Propagation (APSURSI), 2016, pp. 277-278.

[4] L.-Y. Liu, B.-Z. Wang, "Compact broadband linearly and circularly polarized antenna based on CRLH transmission line," Asia-Pacific Microwave Conference (APMC), Vol. 2, 2015, pp. $1-3$.

[5] A. Kahng, J. Jeon, J. Anguera, T. Park, "A compact MIMO antenna using CRLH configuration double-layered folded ring radiations with planar mushroom decoupling structure," IEEE Antennas and Propagation Magazine, Vol. 57, Issue 2, 2015, pp. 123-130.

[6] P.-L. Chi, Y.-S. Shih, "Compact and bandwidth-enhanced zeroth-order resonant antenna," IEEE Antennas and Wireless Propagation Letters, Vol. 14, 2015, pp. 285-288.

[7] H. M. Lee, "A compact zeroth-order resonant antenna employing novel composite right/left-handed transmission-line unit-cells structure," IEEE Antennas Wireless Propag. Lett., Vol. 10, pp. 1377-1380, 2011.

[8] B.-J. Niu, Q.-Y. Feng, "Bandwidth enhancement of asymmetric coplanar waveguide (ACPW)-fed antenna based on composite right/left-handed transmission line," IEEE Antennas Wirel. Propag. Lett., Vol. 12, 2013, pp. 563-566

[9] T. Jang, J. Choi, S. Lim, "Compact Coplanar Waveguide (CPW)-Fed Zeroth-Order Resonant Antennas With Extended Bandwidth and High Efficiency on Vialess Single Layer," IEEE Transactions on Antennas and Propagation, Vol. 59, No. 2, February 2011, pp. 363-392.

[10] P.-L. Chi, Y.-S. Shih, "Compact and Bandwidth-Enhanced Zeroth-Order Resonant Antenna," IEEE Antennas and Wireless Propagation Letters, Vol. 14, 2015, pp. 285-288.

[11] Y. Dong, J. Choi, T. Itoh, "Folded Strip/Slot Antenna with Extended Bandwidth for WLAN Application,"
IEEE Antennas and Wireless Propagation Letters, 2016. IEEE Early Access Articles.

[12] A. A. Chaudhry, J. K. Arif, Z. Ahmed, M. A. Chaudhary, M. B. Ihsan, "Parameter Extraction of Composite Right / Left Handed (CRLH) Transmission Line Unit Cell Using Off Resonance Method", 14th International Bhurban Conference on Applied Sciences and Technology (IBCAST), 2017, pp. 779-781.

[13] N. V. Rajasekhar and D. Sriram Kumar "A miniaturized UWB via-less CRLH-TL loaded CPW fed patch antenna," Microwave and Optical Technology Letters, Vol. 58, No. 10, October 2016, pp: $2485-2492$.

[14] S. K. Sharma and C. Raghvendra Kumar, "A compact zerothorder resonating wideband antenna with dual-band characteristics," IEEE Antenna Wireless Propag Lett, Vol. 14, 2015, pp. 1670-1672.

[15] A. Lai, K. M. K. H. Leong, and T. Itoh, "Infinite wavelength resonant antennas with monopolar radiation pattern based on periodic structures," IEEE Trans. Antennas Propag., Vol. 55, 2007, pp. 868-876.

[16] T. Jang, J. Choi, and S. Lim, "Compact coplanar waveguide (CPW)-fed zeroth-order resonant antennas with extended bandwidth and high efficiency on vialess single layer," IEEE Trans. Antennas Propag., Vol. 59, 2011, pp. 363-372.

[17] J. Zhu and G. V. Eleftheriades, "A compact transmission-line metamaterial antenna with extended bandwidth," IEEE Antennas Wireless Propag. Lett., Vol. 8, 2009, pp. 295-298.

[18] C. Lai, S. Chiu, H. Li, and S. Chen, "Zeroth-order resonator antennas using inductor-loaded and capacitor-loaded CPWs," IEEE Trans. Antennas Propag., Vol. 59, 2011, pp. 3448-3453.

[19] J. Zhu and G. V. Eleftheriades, "Dual-band metamaterialinspired small monopole antenna for WiFi applications," IET Electron. Lett., Vol. 45, No. 22, 2009, pp. 1104-1106. 